\title{
Cyprus in Turkish Poetry İbrahim Zeki Burdurlu and Arif Nihat Asya the Impact of Cyprus
}

\author{
Esra Karabacak $^{1, *}$ \\ ${ }^{1}$ Near East University, Faculty of Art and Sciences, Department of Turkish Language and Literature, \\ 99138, Northern Cyprus, Mersin 10 Turkey.
}

\begin{abstract}
Ibrahim Zeki Burdurlu and Arif Nihat Asya, who worked as teachers in Cyprus, expressed their impressions of Cyprus and shared the problems faced by the Turkish Cypriots. Ibrahim Zeki Burdurlu has a very soft expression. When history and Cyprus come together, the values of a literature teacher extending from Namı Kemal to Gazi Kemal are expressed. Arif Nihat Asya was a teacher in Cyprus and wrote poems similar to that of İbrahim Zeki Burdurlu. Probably the indifference of the measure and the occasional immeasurability, which are among the elements of Burdurlu's poetry, have aroused influence in Turkish Cypriot poetry. In the meantime, although the understanding of populist poetry nurtured the understanding of easy-to-write poetry, it was effective in Burdurlu's poems. In this study, Cyprus, Ibrahim Zeki Burdurlu and Arif Nihat Asya's poems in post-Republic Turkish poetry will be examined comparatively with example poems by completing them especially in terms of using language.
\end{abstract}

\section{Introduction}

Post-Republican Turkish poetry In classical Turkish poetry, place names, motives, and historical events have an important place. Emerging movements, under the influence of historical conditions, has gave the Turkish didactic poetry a different shape. Riza Tevfik is one of the 150 people who signed the Sevres Agreement and who were expelled after the Republic due to their attitude towards the National Struggle. In the meantime, it is known that while he was residing in Lebanon, he wrote a letter to Ismail Hikmet Ertaylan, a teacher in Cyprus who respected his poetry, and wanted to have his poems published who in turn invited him to Cyprus and published his poetry book "Sertab-1 Ömrüm" in Nicosia.

Ibrahim Zeki Burdurlu and Arif Nihat Asya, teachers in Cyprus, expressed their impressions of Cyprus and shared the suffering of the Turkish Cypriots. Arif Nihat Asya was a teacher in Cyprus and wrote poems similar to that of İbrahim Zeki Burdurlu.

\footnotetext{
${ }^{*}$ Corresponding author: esra.karabacakeu.edu.tr
} 


\section{Examination}

İbrahim Zeki Burdurlu worked as a teacher at Lefke, Nicosia, Famagusta Turkish high schools (1950-54). Burdurlu, whose first poem was published in Serveti Fünun-Uyanış magazine (1937), was especially known for his poems which took advantage of folk poetry tradition (Ülkü magazine, 1941-45) and influenced by the impressions he lived in.

İbrahim Zeki Burdurlu started teaching at Lefke Middle School in 1950 and later taught Turkish and Literature at Nicosia Turkish and Famagusta Namik Kemal high schools. Burdurlu's years in Cyprus were very fruitful who left Cyprus at the end of the 1953-1954 academicyear. While he was in NicosiaTurkish High School, he published a student magazine called Çığır and another magazine named Namık Kemal while he was at Namık Kemal High School. In addition to his poems which were published in Bozkurt, Hürsöz and Halkın Sesi newspapers, he also published language, literature and magazine reviews, critics and biographies on literature. In his writings with social content, he used the alias “Z. Nuri Dağdaş”. Ibrahim Zeki Burdurlu followed Cyprus Turkish Literature although he never came to Cyprus after he left Cyprus. Burdurlu continued to write poems about Cyprus and his articles were published in Olay journal and Cyprus Mail newspaper until his death. He has pioneered the tradition of writing poetry in Cyprus that is realistic and social. İbrahim Zeki Burdurlu played an important role in the formation of Turkish Cypriot Literature.

Arif Nihat Asya (1904-1957) expressed his impressions of Cyprus and shared the suffering of the Turkish Cypriots. Ibrahim Zeki Burdurlu has an extremely soft expression. $\mathrm{He}$ is a poet who uses language well. While he was a teacher in Cyprus, he was very impressed, and this effect was not limited to a single poem. It expanded from Cyprus to Burdur and into the whole country. His book titled Teeny-Weeny Islandbegins with a poem on Cyprus (Teeny-Weeny Island, 2-3):

\section{A tiny history}

It's like a dot

Look, from the Taurus to the Mediterranean.

There's a burning book there

Each line is a fire

Each meaning is a heap of ember.(Teeny-Weeny Island, 2)

The last poem of the book is titled "Teeny-Weeny Island" which gave its name to the book (Teeny-Weeny Island, 31).

\section{A marine country}

A tiny island

Teeny, weeny.

It is tiny but

Humpback over humpback

The problem is bigger than bigger.

A tiny country
A blindfolded freedom ... Close, very close to Turkey. In this tiny country

Opens, winter-summer starved with a rose Says, "Still, I'm waiting for you," to the Turk(Teeny-Weeny Island, 31

The post deeply missed Turkey in Cyprus. In the poem he wrote for the speaker who ways "This is Turkey here" on the radio, he expressed this feeling of longing, and indicated that radio was the connection with the motherland. He cites a folk song which was sung during National Struggle days. The work is full of impressions of Cyprus from a to $\mathrm{z}$. (Günaydın Yavru Vatan, 52-53) 
The last verse of the poem again expresses the longing for the flag:

Here, buy me a big flag.

The poet also expresses this longing in his poem "The depth of the field":

Al poppy on behalf of the longing in my surrounding

He was saying the Turkish flag and not saying anything else.

Cevdet Çağdaş, one of the Cypriot poets and painters who made the covers and designs of Ibrahim Zeki Burdurlu's books published in Cyprus, tells that he was very impressed with him when he first met him. Ibrahim Zeki reports that he knew Burdurlu from Turkish magazines and Turkish publications, and that he met him when he came to Cyprus as a teacher.Burdurlu not only contented himself with teaching but also tried to popularize literature in Cyprus. In a poem night organized by Cevdet Çağdaş, he told that he prepared a book called Nicosia and asked for his help. He even stated that he wanted to add some drawings in the book.Çağdaş accepted his offer because he liked it very much as a man of art. Thus, the cover of Burdurlu's Teeny-Weeny Island as well as the designs and cover of the book Nicosia are made by Cevdet Çağdaş.

İbrahim Zeki Burdurlu's poems are dominated by three colors. Blue, green and red. Blue is the color of the sea and sky; green is the color of the gardens that give the impression of eternity and red is the color of the flag, hence freedom and Turkishness. Almost every poem in Teeny-Weeny Islandand Günaydın Yavru Cyprus mentions certain places. Such as Paphos Castle, Limassol, Aphrodite Spring in Poli, Lefke, Famagusta, Famagusta Port, My FriendFamagusta Tree, A Dungeon in Famagusta, Barracks Street in Famagusta. Lefke is a poem in which the poet is fascinated with the green of nature. It is also taken to anthologies.

İbrahim Zeki Burdurlu, Lefke poem (Teeny-Weeny Island, 10-11)

Green in green

Lefke, in the green

Earth, green in dreams

Sound, color-color sieved

Breath, called harmony

A whisper is the branches

Green, twig green

Leaf, in green souls,

Earth covered in green blood.

Our way is green

Green, ahead of and behind us

Sky green, earth green ...

That green is not green

(Teeny-Weeny Island, 11)

\author{
Green wrapped in green \\ Green green layer, \\ Green green taste. \\ Time looks like green \\ All lips to green \\ Green is all feet. \\ Green, the essence of humans \\ Green, the eye of humans \\ Lefke has a green \\ Endless day of humans \\ A life green in Lefke; \\ If a color is not in this tone
}

Maybe it's good to hang those poems in the places they define. These are the poems of love.

Besides the services provided by Ibrahim Zeki Burdurlu to the culture and literature of Cyprus, we see that there is a side that both produces and promotes production in Cyprus. Thus, we can say that it is an important signature not only with his poems about Cyprus but also for his contributions to Turkish Cypriot Literature.The collection of İbrahim Zeki Burdurlu's articles published in newspapers and magazines in Cyprus according to the contents will play an important role in illuminating the social and communal structure of the period. The point that Cypriot writers have in common is that Ibrahim Zeki Burdurlu did a very useful work in Cyprus.Ibrahim Zeki Burdurlu, who tried to reconcile modern 
poetry with folk poetry technique, added a distinctive feature to his poetry by including the local colors and values in Burdur and other Anatolian cities where he has worked.

The mythology-affected history, legends, friendly and beautiful faces of Cyprus inspired the poet. As he told in the poem "to the kebab man", all of them accompanied the poet during dinner:

Flip, flip skewers kebab man

Turn the kebabs!

Look, it's evening

Destemona is on the road from Famagusta

Aphrodite also comes from Paphos...

Flip, flip skewers, kebab man!

The apprentice, fill the goblets,

Now all vineyards of Cyprus
Here Destamona

Are in this old wine;

In the color of this old wine

Are all Mediterranean suns...

Flip, flip skewers kebab man!...

Look, two stars are calling

From the age of first steep

I will sit here

In the poem titled "Evening Star of Famagusta" the poet mentions the Othello Tower.

Come, I am at Othello Bastion!

My face looking at the sea,

My inside is sea from one end to the other;

Come, come the evening star

We are on our own.

Aphrodite will drink from this goblet.......(Teeny-Weeny Island, 13)

In "Pomegranate" Tree poem he asks to the reddened tree: (Teeny-Weeny Island, 18-19)

Pomegranate Tree, Pomegranate Tree In my very dear Turkey

You know what a flag is?

For soul, for the homeland

For freedom, for freedom

For those who are buried in the homeland

Would you die, pomegranate tree?

One dies without blinking his eye

In my country

After these verses, the poet remembered the flag:

I fell apart from my flag in Cyprus

Ifell apart from that blood fresh red of mine.

My love for you is for this, the pomegranate tree,

For longing for red waves;

For this, I liked your green for my homeland

Your flowers for my flag,

I burned in your shadow with the wood of longing

I pulled your beauty.
I fumed like Anatolia;

For this reason, pomegranate tree, My mountain-like longing

I melted with your red flowers;

To the apples of my eyes

Like a red flag

The poet remembers history as well as nature. He tells the conquest of Nicosia by the Turks and the excitement of the past days in his poem "Bayraktar" (Günaydin Yavru Kibris, 32). When history and Cyprus come together, the values that reacha literary teacher from Namık Kemal to Gazi Kemal are expressed:
Namık Kemal!
My free storm,
Is my mother,
My free gazelle;
This freedom
This freedom
Is my father
(Günaydın Yavru Kıbrıs, 24) 
The last poem of Günaydın Yavru Kıbrıs is "The Cyprus Dream" which explains the longing for freedom (Günaydın Yavru Kıbrıs, 60-61).

Arif Nihat Asya, on the other hand:

You have mountains, you have a plains; you have everything!

They call you a small, miniature continent ...

Yes, a continent you are...A continent of poetry.

With a footnote, the poet explains that the word "continent" in the end of the Cyprus verse can be replaced by the word "requiem": The word "poem" can be replaced by "requiem".

Arif Nihat Asya was a teacher in Cyprus, and he wrote poems similar to that of İbrahim Zeki Burdurlu. However, Arif Nihat Asia has a bitterness that entails black humor, both because he has a rawer attitude and because the conditions of the Turkish Cypriots become very grave as of the period. In his poem "Cyprus in Blood" he says:

Tell me, O Islet why

The sky and ground is in smoke?

Where is the past and future;

It all happened in the moment!

A ğla Arif Nihat, cry(Prayers and Amens, 194.)

There are victims in Cyprus,

Who float in blood!

Some would be brave

After growing over time;

Some are golden already

Were honeycombs in the beehive

Your wild and tour bandits

Are among those who shoot in the heart

How did they slaughter this one

He carried a life in her life!

It means two martyrs at the same time

A victim inside a victim!

Cry Arif Nihat, cry

For those who cannot cry!

It is seen in his compiled proses that Arif Nihat Asya thinks of Cyprus frequently. In his 30 August 1964 dated essay titled "Kocatepe" he confesses that he cannot stop thinking miserable things and says "now the echo in myself cries "Green island among islands". "Wedding Gift" is a striking example of black humor. The text begins as "I am invited to the wedding of Greek King Konstantin and Princess of Denmark, An Mari”. He says that he knows very well what the best wedding gift is. But instead of what I had hoped, I will take a magnified picture of the four dead in a bathroom, placed in an ebony frame. I want this painting to decorate An Mari's bathroom in the royal palace!" (A flag waiting for wind, 13)

The movement which began in 1950 around the Hisar journal against pure-Turkish school defended the values of our old poetry and kept the spectrum of poetry as broad as possible. Arif Nihat Asya and İbrahim Zeki Burdurlu were among the poets who published their poems in Hisar. Nevzat Yalçın also published his poems in Hisar and one of his books was published by Hisar Publications. Nevzat Yalçın, a Cypriot living in Germany, was urged to think about the past and present of Cyprus by the landscape on a card sent from his homeland. 
A postcard comes from Cyprus: a view of the sky and the sea;

Clouds igniting the opposite horizon are burning:

Sunset at PetraduRomyu: Sunset on the Greek Rock."

But it's the night of the war, a ball shot behind that cape.

Somewhere, the canyons of Piyale Pasha

$\mathrm{He}$ is in the navy with the songs of Victory.

Three crescents and three hundred years ... the bloodshed is eternal ...

It's too much to say, just yesterday, without frost.

Greek boy sets claim on this forbidden, bloody legacy

(Prayers and Amens, 68-69)

Arif Nihat Asya, who is known for his nationalist poems, wrote poems about the beauty and nature of the country; he made criticism sometimes but also glorified Turkishness. In his poems, verse forms of folk and divan literature are included as well as verse forms of modern literature. The most commonly used verse is rubaid; He has written five books of rubaians. His main themes are heroism and sense of history, religion, love, nature and beauties of the country. He has a simple style which used daily Turkish language as an art language in his poems. His proses deal with social and political issues, observations of the country, friends, close environment, historical issues, religious issues, love, and nature. In 1964, he published his book, the Rubai of Cyprus, and said that he did not break his ties with Cyprus and that on his deathbed at the hospital before his death $(5$ January 1975), whose last poem was about Cyprus. Arif Nihat Asia's poem which he wrote in the last days of his life is as follows:

Who would say, the history we spent together, One day Cyprus would be fairy tale!

But do not grieve, a part of your existence

At the end of his book titled "Cypriot Rubaids", he added the writings titled "How do we lose Cyprus?", "This is the language they speak" and "The Road to Kyrenia". In these writings, Asya stated that it is necessary to raise the issue of islands from time to time in order not to let the world forget that we have a right to all Mediterranean and Aegean islands. Not from the viewpoint of "we do not have any claim on anyone's land", but due to the misunderstanding related to its content, he adopted the view that we could lose Cyprus. Common language and literature that come to the body have the quality of feeding each other. This is a critical point.

\section{Conclusion}

As a result, minor evaluations were made here that could be used as a source for further studies on the elements that shaped the Cyprus poetry within the Turkish Cypriot Literature. Studies in this direction should be expanded. Mere reading the historical information and poems in a straight line can only lead to the emergence of data. Language is common, it has a wide audience. Here, only two important writers of Turkish literature and their traces in Cyprus have been examined. Recognizing the world literature in Turkish literature, some of them have found a place in it. Some have contributed by adopting a new identity and looking for new ones. Although the men of letters feel the need to think about situations, we cannot always say that they find the truth. When they find beauty, it is inevitable for authors to accept it, even if the idea is not correct.

It is appropriate to complete the study with the following words of the Cypriot researcherwriter Oğuz Yorgancıŏlu. 
Nation lives with its language

Life goes beyond time

Those who forget their identity

Show me, where do they live?(p.104)

\section{References}

1.Burdurlu, İbrahim Zeki , Teeny-weeny Island (Nicosia, 1953a)

2.Burdurlu, İbrahim Zeki.Good Morning Yavru Cyprus. Nicosia, Sound of the People

Publishing, 1959b)

3. Asya, Arif Nihat, All works poems: 2 Prayers and Amens (Istanbul, Otuken Publishing House, 1976a)

4.Asya, Arif Nihat, A Flag is waiting for the wind (Istanbul, Otuken Publications, 9th edition. 1999b) 